\title{
Bangkit Pascainfeksi: Dinamika Resiliensi pada Penyintas Covid-
}

19

\author{
Yudi Kurniawan', Markus Nanang Irawan Budi Susilo² \\ 1,2Fakultas Psikologi Universitas Semarang \\ e-mail:1yudikurniawan@usm.ac.id
}

Article History:

Received

28 April 2021

Review

14 Mei 2021

Revised

10 Juni 2021

Accepted

11 Juni 2021

Published

23 Juni 2021

Reviewer A:

Sri Lestari
Abstract. This study aims to qualitatively understand the dynamics of resilience in COVID-19 survivors. Survivors of COVID-19 are still symptomatic for more than 60 days after first onset. This condition is known as long COVID. In addition to long COVID, survivors also face the risk of stigmatization from an environment that is burdensome for patients who have recovered to be able to return to normal activities. This study uses a phenomenological approach. Researchers conducted in-depth interviews with four respondents who had tested positive for COVID-19 based on PCR swab results and experienced several long COVID symptoms. Researchers found that the dynamics of resilience in COVID-19 survivors in this study emerged as an interaction between protective factors and risk factors. The risk factors experienced by participants in this study were social stigma and the long-term impact of COVID-19. The protective factors that became the main themes of the participants were adaptive mindset, ability to manage emotions, social support, and spirituality.

Keywords: pandemic, COVID-19 survivors, resilience, long COVID, social stigma

Abstrak. Penelitian ini bertujuan untuk memahami secara kualitatif dinamika resiliensi pada penyintas COVID-19. Penyintas COVID-19 masih bergejala hingga lebih dari 60 hari setelah onset pertama muncul. Kondisi ini dikenal sebagai long COVID. Selain long COVID, penyintas pun menghadapi risiko stigmatisasi dari lingkungan yang memberatkan pasien yang telah pulih untuk dapat kembali berkegiatan secara normal. Penelitian ini menggunakan pendekatan fenomenologi. Peneliti melakukan wawancara mendalam terhadap empat responden yang pernah dinyatakan positif COVID-19 berdasarkan hasil swab PCR dan mengalami beberapa gejala long COVID. peneliti menemukan bahwa dinamika resiliensi pada penyintas COVID-19 dalam penelitian ini muncul sebagai interaksi antara faktor protektif dan faktor risiko. Faktor risiko yang dialami oleh partisipan dalam penelitian ini adalah stigma sosial dan dampak jangka panjang COVID-19. Faktor protektif yang menjadi tema utama partisipan adalah pola pikir adaptif, kemampuan mengelola emosi, dukungan sosial, dan spiritual.

Kata kunci: pandemi, penyintas COVID-19, resiliensi, long COVID, stigma sosial

\section{Pendahuluan}

Organisasi Kesehatan Dunia (WHO) menetapkan Coronavirus Disease (COVID-19) sebagai pandemi pada 11 Maret 2020. Merujuk pada Kamus Besar Bahasa Indonesia 
(KBBI), pandemi merupakan wabah yang berjangkit serempak di mana-mana, meliputi daerah geografis yang luas dan lintas benua (Setiawan, 2012). Penetapan status pandemi dilakukan atas masifnya penyebaran virus yang secara geografis telah mencapai lebih dari 200 negara, termasuk Indonesia. Merespons situasi darurat, Presiden Joko Widodo menyampaikan pidato pada tanggal 15 Maret 2020 yang salah satu pesannya adalah meminta masyarakat untuk bekerja, belajar, dan beribadah dari rumah. Selain beraktivitas dari rumah, masyarakat juga diwajibkan melakukan physical and social distancing yang menjadi protokol bila seseorang terpaksa harus berkegiatan di luar rumah (Kementerian Kesehatan, 2020).

Taylor (2019), dalam bukunya yang berjudul The Psychology of Pandemics, menjelaskan kondisi pandemi sebagai situasi di mana infeksi suatu jenis penyakit menular yang telah menyebar di seluruh benua di dunia. Pandemi merupakan ancaman kesehatan global dan menyebabkan kelumpuhan di nyaris seluruh sektor karena membatasi aktivitas manusia. Dalam kondisi demikian, ada tiga hal yang dapat terjadi pada individu, yaitu: kemampuan adaptasi, ketidakpastian, dan perubahan perilaku.

Pada situasi pandemi COVID-19, ada dua kelompok masyarakat berdasarkan kondisi kesehatan yang dialami, yaitu belum/tidak terinfeksi dan sedang/telah terinfeksi. Ada kecenderungan perbedaan kondisi emosional dan cara berpikir pada individu yang belum dan telah terinfeksi. Pasien positif COVID-19 sendiri masih terbagi ke dalam beberapa kategori, yaitu positif tanpa gejala, positif bergejala ringan, positif gejala sedang, dan positif gejala berat (Kesehatan, 2020).

Hingga awal April 2021, tercatat lebih dari 1,5 juta akumulasi kasus positif COVID19 di Indonesia yang terdata sejak awal Maret 2020. Dari jumlah tersebut, terdapat 41.669 kematian akibat COVID-19 dan 1,3 juta pasien yang dinyatakan negatif COVID-19 berdasarkan hasil swab dengan metode analisis Polymerase Chain Reaction (PCR) dan pasien tanpa gejala yang telah menyelesaikan masa isolasi selama 14 hari (Satgas COVID19, 2021). Kelompok pasien yang telah melewati masa isolasi dan perawatan ini disebut sebagai penyintas COVID-19.

Dalam sejarah pandemi global, wabah penyakit yang tersebar luas dan menimbulkan banyak korban jiwa tak hanya memberikan dampak pada aspek kesehatan fisik, tetapi juga berakibat pada sisi kesehatan mental dan sosial. Kala wabah Black Death terjadi di Eropa periode 1346-1353, orang Yahudi mengalami persekusi karena dituduh telah meracuni dan sumur. Padahal pada kenyataannya, wabah ini disebabkan oleh bakteri Yersinia pestis (Ravando, 2020). Pandemi COVID-19 pun tak lepas dari stigma 
sosial. Di awal kemunculannya, COVID-19 sempat disebut sebagai Chinese Virus, karena virus ini menyebar secara masif pertama kali di Wuhan, Tiongkok (Ravando, 2020). Faktanya, COVID-19 pertama kali menyebar secara masif di Wuhan, namun belum ada bukti kuat untuk menjustifikasi bahwa COVID-19 merupakan virus rekayasa yang sengaja disebar oleh negara tertentu, termasuk Tiongkok (Shereen, Khan, Kazmi, Bashir, Siddique, 2020). Stigma sosial semacam ini turut berdampak terhadap kondisi psikologis masyarakat, khususnya terhadap pasien dan penyintas.

Siaran pers hasil kolaborasi antara Laporcovid-19 dengan Kelompok Peminatan Intervensi Sosial Fakultas Psikologi Universitas Indonesia menyebutkan bahwa stigma sosial berdampak negatif terhadap pasien dan penyintas COVID 19 (Pelupessy \& Bramanwidyantri, 2020). Survei yang dilakukan terhadap 181 partisipan tersebut menemukan bahwa stigma dapat memicu perasaan khawatir, emosi sedih, takut, dan kecewa pada 51 persen partisipan (Pelupessy \& Bramanwidyantri, 2020). Bila dibiarkan berlarut, stigma sosial negatif dapat memicu masalah kesehatan mental yang lebih serius pada pasien dan penyintas.

Salah satu contoh stigma terlihat pada kasus pertama COVID-19 di Indonesia, yang disebut sebagai pasien 01 dan 02. Saat informasi kasus positif tersebar di media massa, segala hal pribadi yang terkait dengan pasien 01 dan 02 turut turut beredar di dunia maya. Mulai dari alamat rumah, pekerjaan, tetangga, hingga hal-hal lainnya yang tak ada sangkut paut langsung dengan COVID-19. Akibatnya, pasien 01 dan 02 merasa tidak nyaman secara emosional. Selain itu, warga di sekitar tempat tinggal pasien 01 dan 02 pun turut terkena dampak karena tinggal satu wilayah dengan pasien yang positif COVID-19 (Rizkiayu, 2020). Stigma sosial turut memperberat pemulihan psikologis bagi pasien dan penyintas. Di Indonesia ditemukan beberapa kasus di mana penyintas tidak diterima oleh lingkungan sosialnya setelah selesai menjalani masa perawatan di rumah sakit (Rizkiayu, 2020).

Dalam konteks kesehatan, stigma sosial merupakan pelabelan atau pengaitan dalam kerangka negatif terhadap seseorang atau sekelompok orang yang memiliki kesamaan ciri atau memiliki penyakit tertentu (UNICEF \& WHO, 2020). Dalam situasi pandemi, stigma sosial dapat memberikan ketimpangan akses terhadap individu yang mendapatkan label negatif. Pada kasus di Meksiko, sekelompok dokter dan perawat tidak mendapatkan akses transportasi publik karena dianggap membawa COVID-19. Sementara di India, seorang ibu yang baru saja melahirkan tidak diterima oleh keluarganya hanya karena rumah sakit tempat ia melahirkan juga merawat pasien COVID-19 (Bagcchi, 2020). Di Indonesia, ada 
kasus di mana penyintas diberhentikan dari pekerjaan karena waktu perawatan yang cukup lama akibat COVID-19. Selain itu, ada beberapa penyintas COVID-19 yang jadi bahan pergunjingan oleh tetangga, meskipun telah dinyatakan negatif dari virus tersebut (informasi diperoleh dari percakapan peneliti dengan penyintas COVID-19). Kasus-kasus demikian turut memperberat beban penyintas yang telah mengalami hambatan secara fisik dan ditambah dengan problem emosi serta kesehatan mental akibat tekanan sosial. Stigma sosial tak hanya melekat pada pasien dan penyintas, tetapi juga terhadap keluarga dan tenaga kesehatan yang terkait dengan penanganan dampak pandemi (Singh, Bhutani, dan Fatima, 2020).

Dalam riset terkait pemetaan gambaran risiko psikologis COVID-19 di Indonesia, terdapat empat aspek utama pandemi yang memicu distres, yaitu: pembatasan sosial, kekurangan kebutuhan dasar, ancaman infeksi, dan penyesuaian perilaku (Hakim, 2020). Ancaman infeksi ini termasuk terhadap keluarga dekat pasien maupun pasien yang positif COVID-19 itu sendiri. Situasi tersebut rentan menghadirkan ketidakseimbangan psikologis bagi masyarakat dalam skala mikro maupun makro. Kemudian sebanyak 27 persen dari 1.319 partisipan penelitian mengembangkan stres akut, sementara 72 persen partisipan mampu mengembangkan mekanisme koping positif untuk mengurangi stres (Hakim, 2020). Seharusnya tersedia layanan psikososial lanjutan partisipan yang mengalami stres akut, agar dapat mengurangi risiko munculnya masalah kesehatan mental pada individu, khususnya pada pasien dan penyintas COVID-19.

Pasien yang dikonfirmasi positif COVID-19 dapat mengalami beberapa masalah emosional seperti kecemasan, putus asa, kesedihan mendalam, gejala depresi, masalah tidur, dan ketidakberdayaan. Dalam laporan awal penanganan COVID-19 di Wuhan, ditemukan juga beberapa kasus serangan panik yang dialami oleh pasien (Liang, 2020). Pada kasus di Wuhan, evaluasi psikologis yang dilakukan di ruang isolasi menunjukkan sekitar 48 persen pasien positif COVID-19 mengalami distres psikologis sejak pertama kali masuk rumah sakit. Masalah emosional dipicu oleh respons pasien terhadap stres. Pada pasien yang mengalami kondisi kritis, ditemukan juga gejala delirium (gangguan pada kemampuan mental yang menyebabkan kebingungan dan kurangnya kesadaran terhadap lingkungan sekitar). Bahkan ada laporan ensefalitis (radang otak karena infeksi) yang dipicu oleh SARS-CoV-2 memicu gejala psikologis seperti mudah marah dan tidak sadarkan diri (Liang, 2020).

Risiko masalah kesehatan mental tak berhenti saat pasien dinyatakan negatif COVID-19. Pada banyak kasus, penyintas COVID-19 masih bergejala hingga lebih dari 60 
hari setelah onset pertama muncul (WHO, 2020). Gejala ini pun ditemukan pada kasus anak dan dewasa muda yang terinfeksi COVID-19 tanpa komorbid. Kondisi ini dikenal sebagai long COVID dan dialami oleh individu yang telah dinyatakan sembuh dari infeksi COVID-19 (berdasarkan hasil swab PCR atau masa isolasi mandiri), tetapi masih mengalami dampak lanjutan kesehatan fisik maupun mental sebagai dampak infeksi virus pada bagian tubuh tertentu (Mahase, 2020).

Studi awal terkait gambaran klinis dan kualitas hidup pada 463 penyintas COVID-19 di Indonesia menunjukkan hasil yang menarik. Sebanyak 294 partisipan (63,5 persen) memiliki gejala lanjutan pasca COVID-19. Gejala ini terdiri atas gangguan fisik dan psikologis seperti batuk, nyeri otot, gangguan kardiovaskular, kelelahan kronis, anosmia, diare, gangguan tidur, kecemasan, dan gangguan konsentrasi (Susanto, 2021). Sekitar 27 persen dari 294 partisipan tersebut mengalami masalah psikologis seperti gangguan tidur, kecemasan, gangguan konsentrasi, dan depresi. Kondisi ini berdampak terhadap proses pemulihan dan kualitas hidup penyintas. Berdasarkan informasi yang peneliti dapatkan lewat grup COVID Survivor Indonesia, ada penyintas yang mengalami masalah di tempat kerja dan lingkungan sosial karena mengalami long COVID. Kondisi fisik dan psikis yang belum sepenuhnya pulih disalahartikan sebagai ketidakmampuan penyintas dalam bekerja, sehingga terjadi beberapa kasus pemutusan hubungan kerja yang dialami oleh penyintas.

Kombinasi antara masalah fisik dan psikologis membuat penyintas rentan mengalami masalah emosi dan kecemasan (Singh dkk., 2020). Dalam banyak kasus, pasien yang telah pulih dari infeksi COVID-19 mengalami penolakan oleh komunitasnya. Stigma yang terkait dengan pandemi dan infeksi menular sangat memicu stres. Pada penyintas, pengalaman selama melakukan karantina atau isolasi dapat menginisiasi respons emosional yang beragam, seperti kecemasan, gangguan tidur, serangan panik, hingga gejala trauma (Singh dkk., 2020). Efek psikologis akibat pemulihan pascainfeksi ditambah dengan stigma berdampak signifikan terhadap keberfungsian penyintas dalam kehidupan sehari-hari (Taylor, 2019). Oleh karena itu, penyintas COVID-19 menghadapi tantangan besar agar mampu bangkit dan pulih secara fisik maupun psikologis.

Untuk mengetahui bagaimana proses pemulihan psikologis dan faktor apa saja yang mempengaruhi daya lenting penyintas, peneliti melakukan wawancara awal dengan partisipan penyintas COVID-19. Partisipan pertama (R1, laki-laki, karyawan swasta, lajang) merupakan penyintas yang terinfeksi COVID-19 pada periode Maret-Mei 2020. Pada periode Maret 2020, informasi mengenai proses penapisan, asesmen, dan diagnosis 
COVID-19 cenderung belum tersusun secara sistematis. R1 yang mengalami gejala batuk, tidak nyaman di tenggorokan, dan hilang kemampuan perasa pada awal Maret tidak merasa curiga bahwa itu merupakan gejala COVID-19. Selama hampir dua pekan R1 berobat jalan namun gejala yang dirasakan tidak berkurang. R1 kemudian menjalani perawatan di rumah sakit pada tanggal 27 Maret dengan dugaan awal mengalami bronkopneumonia. R1 mendapatkan swab PCR pada tanggal 30 Maret karena dokter mencurigai indikasi terinfeksi COVID-19. Hasil swab baru keluar pada tanggal 15 April dan R1 dinyatakan positif COVID0-19. R1 yang saat itu sudah diperbolehkan pulang dan menjalani isolasi mandiri berinisiatif untuk ke Wisma Atlet agar mendapatkan pengawasan dari tenaga medis. R1 menjalani isolasi di Wisma Atlet hingga 2 Mei 2020 (wawancara R1, 2 Januari 2021).

Persoalan lain muncul pasca R1 dinyatakan negatif COVID-19. R1 merasakan beberapa gejala seperti ada yang menusuk di sekujur tubuh, dada berdebar (palpitasi), nyeri tenggorokan, tinitus, dan pembesaran kelenjar getah bening. R1 sempat berkonsultasi dengan beberapa dokter terkait dengan gejala tersebut. Setelah dirawat di Wisma Atlet, R1 sempat mendapatkan observasi selama delapan hari di rumah sakit dan berdasarkan pemeriksaan medis R1 dinyatakan dalam keadaan normal. Oleh dokter yang melakukan perawatan, R1 dianggap terlalu memikirkan COVID-19 dan sebaiknya rileks saja karena karena kondisinya sudah dinyatakan negatif COVID-19. Tetapi kondisi yang kemudian diketahui sebagai long COVID tersebut membuat aktivitas sehari-hari R1 tidak dapat dilakukan secara optimal.

Berdasarkan pengalamannya berinteraksi dengan pasien HIV, R1 memahami bahwa ada gejala lanjutan dari sebuah penyakit yang disebabkan oleh virus (wawancara R1, 2 Januari 2021). Berdasarkan penelusuran informasi dan komunikasi yang dilakukan oleh R1 dengan komunitas penyintas COVID-19 dari beberapa negara (India, Singapura, Hong Kong), R1 menemukan bahwa fenomena long COVID banyak dialami oleh penyintas lain di seluruh dunia. R1 kemudian mewakili penyintas Indonesia untuk berdiskusi tentang dampak COVID-19 dengan Sekretaris Jenderal Perserikatan Bangsa-Bangsa (PBB) pada Juni 2020. Pertemuan tersebut memberikan keyakinan pada R1 untuk menginisiasi komunitas penyintas COVID-19 Indonesia (COVID Survivor Indonesia-CSI) pada Agustus 2020. Hingga pertengahan April 2021, CSI telah memiliki lebih dari 2.000 anggota di Facebook dan 8.445 pengikuti di Instagram.

Sebagai penyintas, R1 telah melalui fase pemulihan dan bangkit untuk menghadapi dampak fisik dan psikologis infeksi virus terhadap tubuhnya. Pengalaman tidak 
menyenangkan pun dialami oleh Partisipan 2 (R2, perempuan, menikah, mahasiswa S1/ibu rumah tangga) yang mendapatkan penolakan oleh warga kampungnya saat akan melakukan isolasi mandiri di rumah. Selain penolakan, pascanegatif COVID-19, R2 masih mengalami beberapa gejala lanjutan seperti tubuh mudah lelah, penurunan kemampuan indra perasa, dan anosmia. Meski pernah mendapatkan stigma saat dinyatakan positif COVID-19, R2 memilih untuk tidak terbawa perasaan negatif. Setelah pulih, R2 memilih untuk menjadi edukator pencegahan COVID-19 di lingkungan terdekatnya.

Partisipan 3 (R3, laki-laki, peneliti, menikah) dan Partisipan 4 (R4, perempuan, aparatur sipil negara/psikolog klinis, menikah) juga mendapatkan stigma dari lingkungan terdekat. Rumah R3 diberikan stiker yang tertulis rumah ini sedang karantina mandiri. Selain itu, rumah R3 ditunggu oleh hansip, sesuatu yang tidak pernah terjadi sebelum COVID-19. Baik R3 dan R4 merasa tidak nyaman secara emosional dengan stigma tersebut, tetapi kedua partisipan memilih untuk tidak larut dalam masalah. Pasca dinyatakan negatif COVID-19, kedua partisipan memilih untuk menjadi edukator pencegahan COVID19 , baik secara langsung atau melalui media sosial.

Keempat partisipan memiliki pengalaman tidak menyenangkan selama proses perawatan dan pemulihan akibat infeksi COVID-19. Dengan tekanan psikososial yang dialami oleh pasien dan penyintas COVID-19, peneliti tertarik untuk mencermati bagaimana keempat partisipan dapat bangkit melawan stigma dan dampak fisik pasca dinyatakan negatif dari virus. Dalam konteks psikologi, ketahanan mental emosional untuk bangkit dari krisis dan masalah disebut dengan resiliensi (Walsh, 2020). Konsep resiliensi menjelaskan kemampuan individu dalam menghadapi kesulitan, hambatan, dan trauma dengan langkah yang adaptif serta mengoptimalkan faktor protektif (Reivich \& Shatté, 2002). Resiliensi menekankan terhadap proses dinamis yang melibatkan interaksi antara faktor protektif, strategi koping, dan meminimalkan dampak faktor risiko (Hendriani, 2018).

Dalam konteks pandemi, resiliensi muncul sebagai interaksi antara kemampuan individu dan fungsi sosial. Kesejahteraan psikologis keluarga berdampak terhadap kemampuan individu untuk pulih dan bangkit dari tekanan psikososial (Prime, Wade, \& Browne, 2020). Kerangka teori resiliensi keluarga melihat bahwa transformasi perilaku individu yang mengalami tekanan psikososial akibat COVID-19 dapat diinisiasi oleh adaptasi positif yang diberikan oleh keluarga inti penyintas (Walsh, 2020). Berdasarkan asesmen awal terhadap empat partisipan dan kerangka teori, fokus kajian dalam penelitian ini adalah dinamika resiliensi yang dialami oleh penyintas COVID-19. Riset ini 
menggunakan pendekatan kualitatif fenomenologi untuk mendapatkan gambaran dinamika dan pengalaman penyintas dalam menghadapi dampak fisik dan psikis infeksi COVID-19.

\section{Metode}

\section{Fokus Penelitian}

Fokus penelitian ini adalah memahami dinamika resiliensi pada penyintas COVID-19. Adapun komponen yang digunakan untuk mengungkap dinamika resiliensi adalah I have, I can, dan I am. Konsep ini digunakan karena peneliti ingin memahami bagaimana unsur kepemilikan, konsep diri, dan kompetensi partisipan dapat berperan untuk menginisiasi resiliensi. Komponen I have bersumber dari faktor eksternal yang terdiri atas akses terhadap fasilitas sosial seperti pendidikan/kesehatan, kepercayaan dalam hubungan sosial, dan dorongan untuk menjadi otonom. Komponen I can bersumber dari kemampuan sosial dan interpersonal untuk menyelesaikan masalah, seperti kemampuan komunikasi, kemampuan penyelesaian masalah, kemampuan pengelolaan emosi, dan kemampuan untuk menjalin relasi yang terpercaya. Komponen I am bersumber dari kekuatan karakter internal seperti persepsi individual bahwa dirinya dicintai, memiliki empati terhadap orang lain, memiliki tanggung jawab terhadap diri sendiri, dan percaya diri. Adapun faktor resiliensi yang menjadi kerangka konseptual dalam penelitian ini adalah kemampuan regulasi emosi, , optimisme, kemampuan analisis sebab akibat, pengendalian impuls, empati, efikasi diri, reaching out (kemampuan untuk meraih aspek positif setelah terjadi peristiwa yang tidak menyenangkan).

\section{Desain Penelitian}

Penelitian ini merupakan riset kualitatif dengan pendekatan fenomenologi. Pendekatan fenomenologi merupakan penelitian reflektif yang menekankan terhadap pengalaman unik individu. Pendekatan fenomenologi berfokus terhadap pengalaman subjektif partisipan lewat perspektif orang pertama (Kahija, 2017). Lewat pengertian tersebut, penelitian fenomenologi dipahami sebagai penelitian reflektif yang dilihat dari pengalaman orang pertama. Tugas peneliti adalah menemukan esensi dari kesadaran yang dialami oleh partisipan. Oleh karena itu, peneliti fenomenologi harus mampu memahami dan menerima bahwa persepsi itu merupakan sesuatu yang relatif, memiliki kemampuan mendengarkan aktif, serta mampu berempati terhadap situasi yang dialami oleh partisipan penelitian (Kahija, 2017).

\section{Partisipan Penelitian}

Kriteria partisipan dalam penelitian ini adalah sebagai berikut: 
a. Laki-laki atau perempuan, usia dalam rentang 18-55 tahun

b. Pernah dinyatakan positif dan negatif COVID-19 berdasarkan hasil swab Polymerase Chain Reaction (PCR)

c. Pernah atau sedang mengalami minimal satu gejala long COVID berdasarkan kriteria WHO

d. Tetap melakukan aktivitas harian (bekerja, sekolah/kuliah, kegiatan rumah tangga, dan sejenisnya) setelah dinyatakan negatif COVID-19.

Partisipan dalam penelitian ini berjumlah 4 (empat) orang dengan data sebagai berikut:

Tabel 1. Data Partisipan Penelitian

\begin{tabular}{|c|c|c|c|c|c|c|}
\hline $\begin{array}{l}\text { Kode } \\
\text { Partisipan }\end{array}$ & $\begin{array}{l}\text { Usia saat } \\
\text { terinfeksi } \\
\text { COVID- } \\
19\end{array}$ & $\begin{array}{l}\text { Jenis } \\
\text { Kelamin }\end{array}$ & Pekerjaan & $\begin{array}{l}\text { Dinyatakan } \\
\text { Positif } \\
\text { COVID-19 }\end{array}$ & $\begin{array}{l}\text { Dinyatakan } \\
\text { Negatif } \\
\text { COVID-19 }\end{array}$ & $\begin{array}{l}\text { Gejala } \\
\text { Lanjutan } \\
\text { Pasca COVID- } \\
19\end{array}$ \\
\hline R1 & 36 th & Laki-laki & $\begin{array}{l}\text { Karyawan } \\
\text { swasta }\end{array}$ & $31 / 03 / 2020$ & $04 / 05 / 2020$ & $\begin{array}{l}\text { Palpitasi } \\
\text { jantung, } \\
\text { tinitus, } \\
\text { pembesaran } \\
\text { kelenjar getah } \\
\text { bening, nyeri } \\
\text { tenggorokkan, }\end{array}$ \\
\hline R2 & 49 th & Perempuan & $\begin{array}{l}\text { Ibu rumah } \\
\text { tangga }\end{array}$ & $17 / 07 / 2020$ & $21 / 09 / 2020$ & $\begin{array}{l}\text { Anosmia dan } \\
\text { kelelahan }\end{array}$ \\
\hline R3 & 44 th & Laki-laki & peneliti & 05/09/2020 & $30 / 09 / 2020$ & \begin{tabular}{l}
\multicolumn{2}{l}{ Anosmia } \\
ringan, sendi \\
pegal jika \\
lelah, sinusitis
\end{tabular} \\
\hline R4 & 32 th & perempuan & $\begin{array}{l}\text { Psikolog } \\
\text { klinis }\end{array}$ & $25 / 11 / 2020$ & $18 / 12 / 2020$ & $\begin{array}{l}\text { Anosmia } \\
\text { ringan, } \\
\text { mudah lelah }\end{array}$ \\
\hline
\end{tabular}

\section{Teknik Pengambilan Data}

Riset ini menggunakan teknik wawancara mendalam untuk pengambilan data. Teknik wawancara mendalam digunakan dalam penelitian kualitatif karena memungkinkan peneliti untuk berinteraksi secara intens dengan partisipan penelitian. Wawancara merupakan perangkat untuk memproduksi pemahaman situasional (situated understanding) yang bersumber dari episode-episode interaksional khusus antara peneliti dan responden (Denzin \& Lincoln, 2013).

Proses pengambilan data untuk riset ini dimulai pertengahan November 2020 hingga pertengahan Januari 2021. Sebagai penyintas COVID-19, peneliti bergabung dalam grup Facebook untuk COVID-19 Survivor Indonesia (CSI) di akhir Oktober 2020. Hingga 19 
Januari 2021, jumlah anggota grup CSI sebanyak 1.153 orang. Koordinator grup ini adalah seorang penyintas COVID-19 yang terinfeksi pada Maret 2020. Berdasarkan pengalamannya yang menjadi salah satu pasien COVID-19 di masa awal pandemi di Indonesia, informasi mengenai pengobatan COVID-19 dan perawatan setelahnya sangat minim. Oleh karena itu, grup CSI dibentuk pada Agustus 2020 dengan tujuan membantu pasien dan penyintas untuk mendapatkan informasi valid seputar pengobatan dan pemulihan pascainfeksi.

Wawancara adalah salah satu metode penting dalam psikologi yang digunakan memperoleh informasi detail dari partisipan. Ada tiga bentuk dasar wawancara, yaitu terstruktur, tak terstruktur, dan wawancara terbuka (open ended) (Denzin \& Lincoln, 2013). Hal tersebut menunjukkan bahwa perangkat wawancara dapat dimodifikasi dan diubah sesuai kebutuhan penelitian. Pertanyaan dalam wawancara juga dapat diperdalam dengan menggunakan teknik probing. Hal ini dilakukan ketika masih ada jawabanjawaban partisipan yang terlalu umum dan belum ditemukan secara jelas tema dari jawabannya. Rset kualitatif ini menggunakan tipe wawancara semi terstruktur, yang memungkinkan peneliti membuat pedoman baku pertanyaan, tetapi tidak menutup kemungkinan untuk melakukan pendalaman materi dan bertanya mengenai hal lain yang ditemukan saat proses wawancara.

\section{Teknik Analisis Data}

Data dalam riset ini dianalisis dengan teknik koding analisis kualitatif. Analisis dan interpretasi data yang digunakan untuk menghubungkan antara temuan lapangan dan kerangka teori. Proses ini disebut dengan pengkodean (pengkodean).

Proses coding dapat dilakukan melalui langkah-langkah berikut (Deterding \& Waters, 2018):

a. Open Coding atau pengkodean terbuka yaitu proses menguraikan, memeriksa, membandingkan, mengonsepkan, dan mengkategorikan data

b. Axial Coding atau pengkodean berporos yaitu prosedur penempatan data dengan membuat keterkaitan antar kategori atau faktor.

c. Selective Coding atau pengkodean berpilih yaitu proses pemilihan kategori atau faktor inti. Proses mengaitkan antara kategori inti terhadap kategori lainnya secara sistematis serta mengganti kategori yang perlu diperbaiki dan dikembangkan lebih lanjut.

Setelah melakukan koding, tahap selanjutnya adalah analisa tematik, yaitu proses mengkoding informasi yang dapat menghasilkan daftar tema, model tema atau indikator yang kompleks. Tema merupakan gambaran atau deskripsi mengenai fenomena yang 
terjadi. Manajemen koding dilakukan dengan berdasarkan urutan wawancara yaitu pelaksanaan wawancara, inisial partisipan, tanggal wawancara, dan baris penyataan partisipan. Misalnya: W1 (pelaksanaan wawacara), KY (inisial partisipan), 25 April (tanggal wawancara), dan b189-193 (baris pernyataan partisipan dalam verbatim).

\section{Hasil}

Dalam penelitian ini, peneliti melakukan wawancara terhadap empat partisipan yang memenuhi kriteria penelitian. Pedoman wawancara yang digunakan oleh peneliti untuk menggali informasi dan memahami dinamika resiliensi pada partisipan adalah sebagai berikut:

Tabel 2. Pedoman Wawancara Komponen Resiliensi

\begin{tabular}{|c|c|c|c|}
\hline $\begin{array}{c}\text { Komponen } \\
\text { Resiliensi }\end{array}$ & Definisi & Indikator & Pertanyaan \\
\hline \multirow{4}{*}{ I have } & \multirow{4}{*}{$\begin{array}{l}\text { Komponen resiliensi } \\
\text { yang berhubungan } \\
\text { dengan besarnya } \\
\text { dukungan sosial } \\
\text { yang diperoleh dari } \\
\text { sekitar sebagaimana } \\
\text { yang dipersepsikan } \\
\text { oleh individu }\end{array}$} & $\begin{array}{l}\text { Relasi yang didasari } \\
\text { oleh kepercayaan }\end{array}$ & $\begin{array}{l}\text { Bagaimana respons } \\
\text { keluarga saat Anda } \\
\text { dinyatakan positif } \\
\text { COVID-19? }\end{array}$ \\
\hline & & $\begin{array}{l}\text { Bentuk relasi dalam } \\
\text { keluarga dan } \\
\text { lingkungan sosial }\end{array}$ & $\begin{array}{l}\text { Bagaimana respons } \\
\text { rekan kerja saat } \\
\text { mengetahui Anda } \\
\text { dinyatakan positif } \\
\text { Covid-19? }\end{array}$ \\
\hline & & $\begin{array}{l}\text { Model peran yang } \\
\text { dijalani dalam } \\
\text { kehidupan sosial }\end{array}$ & \begin{tabular}{lr}
\multicolumn{2}{l}{ Saat Anda terinfeksi } \\
covid, & adakah \\
seseorang & yang \\
menjadi & inspirasi \\
untuk & melewati \\
masalah tersebut? & Bila ada, dapatkah \\
Anda jelaskan \\
bagaimana orang \\
tersebut dapat \\
menginspirasi?
\end{tabular} \\
\hline & & $\begin{array}{l}\text { Dorongan individu } \\
\text { untuk menjadi } \\
\text { mandiri (otonom) }\end{array}$ & $\begin{array}{l}\text { Saat menjalani } \\
\text { isolasi hingg saat } \\
\text { ini, apakah Anda } \\
\text { memiliki } \\
\text { otonomi/kebebasan } \\
\text { untuk menentukan } \\
\text { pilihan? Misalnya }\end{array}$ \\
\hline
\end{tabular}




\begin{tabular}{|c|c|c|c|}
\hline \multirow{3}{*}{$\begin{array}{l}\text { Komponen } \\
\text { Resiliensi }\end{array}$} & Definisi & \multirow[t]{2}{*}{ Indikator } & \multirow[b]{2}{*}{$\begin{array}{l}\text { untuk pengobatan } \\
\text { dan sejenisnya? }\end{array}$} \\
\hline & & & \\
\hline & & $\begin{array}{l}\text { Akses terhadap } \\
\text { fasilitas publik }\end{array}$ & \begin{tabular}{lr}
\multicolumn{2}{c}{ Bagaimana } \\
Anda & mengakses \\
layanan & kesehatan \\
dalam & masa \\
pandemi & COVID ini?
\end{tabular} \\
\hline \multirow[t]{6}{*}{ I Am } & $\begin{array}{l}\text { Sumber resiliensi } \\
\text { yang terkait dengan } \\
\text { kekuatan pribadi } \\
\text { dalam diri individu }\end{array}$ & $\begin{array}{lr}\text { Penilaian personal } \\
\text { bahwa } & \text { diri } \\
\text { mendapatkan } & \\
\text { perhatian } & \text { dan } \\
\text { disukai oleh } & \text { orang } \\
\text { lain } & \end{array}$ & $\begin{array}{l}\text { Saat terinfeksi } \\
\text { covid hingga masa } \\
\text { pemulihan, apakah } \\
\text { Anda meyakini } \\
\text { bahwa diri Anda } \\
\text { mendapatkan } \\
\text { perhatian dari } \\
\text { orang terdekat } \\
\text { (keluarga, teman, } \\
\text { pasangan, dll)? }\end{array}$ \\
\hline & & $\begin{array}{l}\text { Empati dan } \\
\text { kepedulian terhadap } \\
\text { orang lain }\end{array}$ & $\begin{array}{l}\text { Apa yang Anda } \\
\text { pikirkan tentang } \\
\text { diri Anda saat } \\
\text { menjalani } \\
\text { perawatan hingga } \\
\text { masa pemulihan } \\
\text { saat ini? }\end{array}$ \\
\hline & & $\begin{array}{lr}\text { Mampu } & \text { merasa } \\
\text { bangga } & \text { dengan diri } \\
\text { sendiri } & \end{array}$ & 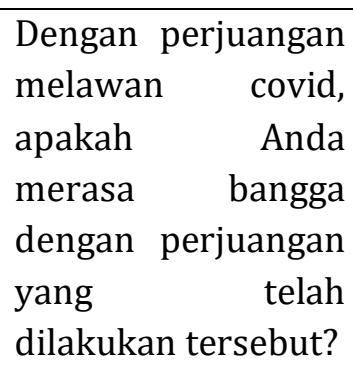 \\
\hline & & $\begin{array}{l}\text { Memiliki tanggung } \\
\text { jawab terhadap diri } \\
\text { sendiri }\end{array}$ & $\begin{array}{lr}\text { Sebagai } & \text { seorang } \\
\text { penyintas, } & \text { apa } \\
\text { tanggung } & \text { jawab } \\
\text { terbesar yang dapat }\end{array}$ \\
\hline & & & $\begin{array}{lr}\text { Anda } & \text { lakukan } \\
\text { terhadap } & \text { diri } \\
\text { sendiri dan } & \text { orang } \\
\text { lain? } & \end{array}$ \\
\hline & & $\begin{array}{l}\text { Optimis dan percaya } \\
\text { diri }\end{array}$ & $\begin{array}{l}\text { Apakah Anda yakin } \\
\text { kondisi diri Anda } \\
\text { akan berubah lebih }\end{array}$ \\
\hline
\end{tabular}


ISSN 2580-6076 (Print), ISSN 2580-8532 (Online)

\begin{tabular}{|c|c|c|c|}
\hline Komponen & Definisi & Indikator & Pertanyaan \\
\hline & & & $\begin{array}{l}\text { baik pasca long } \\
\text { covid? }\end{array}$ \\
\hline \multirow{17}{*}{ I Can } & \multirow{17}{*}{$\begin{array}{lr}\text { Sumber resiliensi } \\
\text { yang terkait } & \text { dengan } \\
\text { upaya } & \text { yang } \\
\text { dilakukan individu } \\
\text { untuk menyelesaikan } \\
\text { masalah menuju } \\
\text { keberhasilan dengan } \\
\text { kemampuan diri } \\
\text { sendiri }\end{array}$} & \multirow{7}{*}{$\begin{array}{l}\text { Kemampuan } \\
\text { komunikasi }\end{array}$} & \multirow{7}{*}{$\begin{array}{l}\text { Bagaimana cara } \\
\text { Anda } \\
\text { berkomunikasi } \\
\text { untuk } \\
\text { menyampaikan } \\
\text { permasalahan yang } \\
\text { ditemukan selama } \\
\text { covid? }\end{array}$} \\
\hline & & & \\
\hline & & & \\
\hline & & & \\
\hline & & & \\
\hline & & & \\
\hline & & & \\
\hline & & \multirow{2}{*}{$\begin{array}{l}\text { Kemampuan } \\
\text { penyelesaian } \\
\text { masalah }\end{array}$} & Bagaimana cara \\
\hline & & & $\begin{array}{l}\text { Anda } \\
\text { berkomunikasi } \\
\text { untuk } \\
\text { menyampaikan } \\
\text { permasalahan yang } \\
\text { ditemukan selama } \\
\text { covid? }\end{array}$ \\
\hline & & \multirow{3}{*}{$\begin{array}{l}\text { Kemampuan } \\
\text { mengelola emosi }\end{array}$} & Bagaimana cara \\
\hline & & & $\begin{array}{lr}\text { Anda } & \text { mengelola } \\
\text { emosi } & \text { selama }\end{array}$ \\
\hline & & & positif covid? \\
\hline & & \multirow{2}{*}{$\begin{array}{l}\text { Kemampuan } \\
\text { memahami emosi } \\
\text { diri sendiri dan orang } \\
\text { lain }\end{array}$} & Bagaimana cara \\
\hline & & & $\begin{array}{l}\text { Anda mengenal } \\
\text { emosi yang muncul } \\
\text { selama fase infeksi } \\
\text { dan pemulihan } \\
\text { covid? }\end{array}$ \\
\hline & & \multirow{3}{*}{$\begin{array}{l}\text { Kemampuan } \\
\text { menjalin relasi yang } \\
\text { terpercaya dengan } \\
\text { orang lain }\end{array}$} & Bagaimana \\
\hline & & & $\begin{array}{lr}\text { Anda } & \text { dalam } \\
\text { menjalin } & \text { relasi } \\
\text { untuk } & \end{array}$ \\
\hline & & & $\begin{array}{l}\text { mengembangkan } \\
\text { jaringan dengan } \\
\text { orang lain selama } \\
\text { positif covid? }\end{array}$ \\
\hline
\end{tabular}

Tabel 3. Pedoman Wawancara Faktor-faktor Resiliensi

\begin{tabular}{|c|c|c|}
\hline Faktor & Definisi & Pertanyaan \\
\hline Regulasi emosi & $\begin{array}{l}\text { Kemampuan untuk tetap tenang } \\
\text { dalam situasi/kondisi yang penuh }\end{array}$ & $\begin{array}{l}\text { 1. Selama terinfeksi covid, apa } \\
\text { situasi yang membuat Anda } \\
\text { tidak nyaman? }\end{array}$ \\
\hline
\end{tabular}




\begin{tabular}{|c|c|c|}
\hline Faktor & Definisi & Pertanyaan \\
\hline & tekanan & $\begin{array}{l}\text { 2. Bagaimana cara Anda } \\
\text { menghadapi situasi yang } \\
\text { tidak nyaman tersebut? }\end{array}$ \\
\hline $\begin{array}{l}\text { Pengendalian } \\
\text { Dorongan }\end{array}$ & $\begin{array}{l}\text { Kemampuan untuk mengelola } \\
\text { keinginan, dorongan, kesukaan, } \\
\text { serta tekanan yang muncul dari } \\
\text { dalam diri }\end{array}$ & $\begin{array}{l}\text { Apa yang Anda lakukan saat } \\
\text { merasakan emosi negatif } \\
\text { yang meluap-luap saat } \\
\text { terinfeksi covid? }\end{array}$ \\
\hline Optimis & $\begin{array}{lc}\text { Kemampuan } & \text { individu untuk } \\
\text { mengatasi } & \text { masalah/kemalangan } \\
\text { yang mungkin terjadi di masa depan }\end{array}$ & $\begin{array}{l}\text { 1. Apa yang Anda pikirkan } \\
\text { saat dinyatakan terinfeksi } \\
\text { covid? } \\
\text { 2. Apakah Anda yakin untuk } \\
\text { bisa pulih seperti sedia kala } \\
\text { seperti sebelum terinfeksi } \\
\text { covid? } \\
\text { 3. Apa langkah yang Anda } \\
\text { lakukan untuk memulihkan } \\
\text { kondisi pasca terinfeksi } \\
\text { covid? }\end{array}$ \\
\hline Analisis kausal & $\begin{array}{l}\text { Kemampuan individu untuk } \\
\text { mengindentifikasi secara akurat } \\
\text { penyebab dari masalah yang sedang } \\
\text { dihadapi }\end{array}$ & $\begin{array}{l}\text { 1. Apa yang menjadi penyebab } \\
\text { Anda terinfeksi covid? } \\
\text { 2. Apakah ada faktor eksternal } \\
\text { yang menyebabkan Anda } \\
\text { terinfeksi covid? }\end{array}$ \\
\hline Empati & $\begin{array}{l}\text { Kemampuan individu untuk } \\
\text { mengenali dan memahami ekspresi } \\
\text { emosional dan psikologis orang lain }\end{array}$ & $\begin{array}{l}\text { Menurut Anda, apakah } \\
\text { lingkungan/orang di sekitar } \\
\text { memberikan perhatian } \\
\text { positif saat Anda terinfeksi } \\
\text { covid? }\end{array}$ \\
\hline Efikasi diri & $\begin{array}{l}\text { Keyakinan bahwa individu mampu } \\
\text { memecahkan masalah yang dialami } \\
\text { dan mencapai kesuksesan }\end{array}$ & $\begin{array}{l}\text { Apa saja aktivitas yang Anda } \\
\text { lakukan untuk tetap } \\
\text { menjaga kondisi fisik dan } \\
\text { psikis selama terinfeksi dan } \\
\text { masa pemulihan covid? }\end{array}$ \\
\hline Reaching out & \begin{tabular}{lccr} 
Kemampuan & \multicolumn{2}{c}{ individu } & untuk \\
mendapatkan & sisi positif & dari \\
kemalangan/kondisi & sulit & yang \\
menimpa & & &
\end{tabular} & $\begin{array}{l}\text { Apakah ada aspek positif } \\
\text { yang Anda peroleh selama } \\
\text { masa terinfeksi dan } \\
\text { pemulihan covid? }\end{array}$ \\
\hline
\end{tabular}

Berikut hasil penelitian untuk keempat partisipan:

\section{Partisipan Pertama (R1)}

Partisipan pertama merupakan seorang laki-laki berusia 36 tahun dan berstatus lajang. Partisipan R1 berprofesi sebagai karyawan swasta di Jakarta. Partisipan R1 terinfeksi COVID-19 pada 31 Maret 2020. Gejala yang dirasakan oleh partisipan adalah tenggorokan gatal, batuk kering, kehilangan kemampuan indera perasa, badan menggigil, diare, mual, dan tubuh lemas. Partisipan mendapatkan perawatan di rumah sakit dan 
belum diduga sebagai pasien terinfeksi COVID-19. Di Maret 2020, sistem deteksi dini swab PCR memang belum dilakukan untuk semua pasien. Sehingga partisipan R1 baru dikenakan swab PCR saat telah selesai perawatan di rumah sakit. Setelah mengetahui bahwa hasil swab PCR tersebut positif, partisipan R1 berinisiatif untuk dirawat di Wisma Atlet. Partisipan R1 langsung diterima oleh petugas di Wisma Atlet untuk dikarantina dan diberikan perawatan.

Selama masa karantina, partisipan R1 tetap berkomunikasi dengan keluarga melalui komunikasi daring dan panggilan video. Dukungan dari keluarga dan tempat kerja menjadi faktor utama yang membantu pemulihan fisik dan psikologis partisipan R1. Selain dukungan keluarga, rekan-rekan di tempat kerja partisipan 1 juga memberikan dukungan moril. Rekan kerja tidak memberikan stigma terhadap partisipan I. Aspek lain yang berperan penting dalam proses resiliensi partisipan 1 adalah kemampuan beradaptasi dengan perubahan. Meskipun dalam situasi isolasi, partisipan mampu untuk membuat rutinitas harian yang membantunya mengatasi kejenuhan. Selain itu, setelah dinyatakan negatif COVID-19 berdasarkan hasil swab PCR pada tanggal 4 Mei 2020, partisipan R1 berinisiatif untuk bergabung dengan penyintas COVID-19 di seluruh dunia dan mencari informasi terkait keluhan yang masih dirasakan pascanegatif COVID-19. Gejala ini dikenal dengan istilah long COVID. Partisipan R1 pun mampu berbuat lebih dengan menginisiasi kelompok penyintas COVID-19 dengan nama COVID Survivor Indonesia. Kelompok ini kemudian menjadi wadah resmi bagi penyintas COVID-19 dari seluruh Indonesia. Lewat komunitas tersebut, partisipan R1 pernah diundang oleh WHO untuk mewakili penyintas Indonesia dalam pertemuan penyintas COVID-19 sedunia pada Agustus 2020.

\section{Partisipan Kedua (R2)}

Partisipan R2 merupakan penyintas COVID-19 berjenis kelamin perempuan dan berusia 49 tahun saat penelitian ini dilakukan. Partisipan R2 dinyatakan positif COVID-19 pada 17 Juli 2020. Partisipan R2 telah berkeluarga dan memiliki empat orang anak. Gejala yang dirasakan oleh Partisipan R2 adalah vertigo, hilang kemampuan pada indera penciuman, demam, mual dan muntah, dan tubuh lemas. Selama dinyatakan positif COVID19, R2 melakukan isolasi mandiri di lantai 2 rumah, di tempat terpisah dari anggota keluarga lain. Menurut R2, keluarga memberikan dukungan penuh selama masa isolasi. Stigma muncul dari lingkungan sekitar yang cenderung menjauhi warga yang diduga positif COVID-19. Selain dukungan keluarga, kemampuan koping stres selama masa isolasi menjadi aspek yang menentukan kemampuan resiliensi partisipan.

\section{Partisipan Ketiga (R3)}


Partisipan R3 (laki-laki) merupakan mahasiswa doktoral di Australia National University. Selama pandemi, partisipan R3 berada di Indonesia. Partisipan AS dinyatakan positif COVID-19 pada 5 September 2020 dengan gejala demam, nyeri sendi, hilang kemampuan penciuman, dan batuk kering. Partisipan R3 menjalani isolasi dan perawatan di rumah sakit bersama dengan kedua orangtuanya. Kondisi yang membuat AS khawatir adalah istrinya yang di saat tersebut sedang hamil tua dan akan melahirkan. Aspek utama yang membantu proses resiliensi pada partisipan R3 adalah dukungan keluarga dan pola pikir adaptif untuk menghadapi masalah.

\section{Partisipan Keempat (R4)}

Partisipan R4 (perempuan) merupakan psikolog klinis yang bertugas di Rumah Sakit Umum Daerah Konawe Utara, Sulawesi Tenggara. Partisipan R4 berusia 32 tahun dan sudah menikah. Partisipan R4 dinyatakan positif COVID-19 pada 25 November 2020 dengan gejala nyeri persendian, batuk, pusing, diare, dan hilang kemampuan penciuman. Partisipan R4 dirawat di rumah sakit khusus COVID-19 bersama dengan suaminya yang juga positif COVID-19. Selama positif, Partisipan R4 sempat mendapatkan stigma negatif dari rekan-rekannya sesama tenaga kesehatan. Setelah dinyatakan negatif COVID-19 pada 18 Desember 2020, partisipan R4 masih merasakan gejala lanjutan seperti badan pegal dan tubuh yang mudah lelah bila dibandingkan dengan kondisi sebelum terinfeksi COVID19. Aspek utama yang membantu proses resiliensi pada partisipan $\mathrm{R} 4$ adalah dukungan dari keluarga dan pola pikir adaptif saat menghadapi situasi yang tidak menyenangkan.

Tabel 4 berikut ini menjabarkan indikator komponen dan faktor resiliensi yang ditemukan pada keempat partisipan.

Tabel 4. Temuan Penelitian

\begin{tabular}{|c|c|c|}
\hline \multirow{2}{*}{ Partisipan } & \multicolumn{2}{|l|}{ Resiliensi } \\
\hline & Komponen & Faktor \\
\hline & $\begin{array}{l}\text { Relasi yang didasari oleh kepercayaan (I } \\
\text { have) }\end{array}$ & Regulasi emosi \\
\hline & $\begin{array}{lccc}\text { Bentuk relasi dalam } & \text { keluarga dan } \\
\text { lingkungan sosial (I have) } & & \\
\end{array}$ & Pengendalian impuls \\
\hline & $\begin{array}{l}\text { Model peran yang dijalani dalam kehidupan } \\
\text { sosial (I have) }\end{array}$ & Optimisme \\
\hline & $\begin{array}{l}\text { Dorongan individu untuk menjadi mandiri } \\
\text { (otonom) (I have) }\end{array}$ & Pemahaman sebab akibat \\
\hline & Akses terhadap fasilitas kesehatan (I have) & Empati \\
\hline & $\begin{array}{l}\text { Penilaian personal bahwa diri mendapatkan } \\
\text { perhatian dan disukai oleh orang lain ( } \mathrm{I} \mathrm{am} \text { ) }\end{array}$ & Efikasi diri \\
\hline & Memiliki empati terhadap orang lain ( $\mathrm{am}$ ) & $\begin{array}{ll}\text { Kemampuan melihat sisi } \\
\text { positif dari kemalangan }\end{array}$ \\
\hline & $\begin{array}{l}\text { Bertanggung jawab terhadap diri sendiri (I } \\
\text { am) }\end{array}$ & \\
\hline & Optimis dan percaya diri $(\mathrm{I} \mathrm{am})$ & \\
\hline
\end{tabular}


Kemampuan komunikasi (I can)

Kemampuan penyelesaian masalah (I can)

Kemampuan mengelola emosi (I can)

Kemampuan memahami emosi diri sendiri

dan orang lain (I can)

Kemampuan menjalin relasi yang

terpercaya dengan orang lain (I can)

Hubungan yang dilandasi oleh kepercayaan Regulasi emosi

(I have)

Bentuk relasi dalam keluarga dan Pengendalian impuls

lingkungan sosial (I have)

Model peran yang dijalani dalam kehidupan Optimisme

sosial (I have)

Dorongan individu untuk menjadi mandiri Pemahaman sebab akibat

(otonom) (I have)

Akses terhadap fasilitas kesehatan (I have) Empati

Penilaian personal bahwa diri mendapatkan Efikasi diri

perhatian dan disukai oleh orang lain $(\mathrm{I} \mathrm{am})$

Memiliki empati, kepedulian, dan cinta Kemampuan melihat sisi

terhadap orang lain $(\mathrm{I} \mathrm{am})$

positif dari kemalangan

Memiliki tanggung jawab terhadap diri

sendiri ( I am)

Optimis dan percaya diri ( $\mathrm{I} \mathrm{am})$

Kemampuan komunikasi (I can)

Kemampuan penyelesaian masalah (I can)

Kemampuan mengelola emosi (I can)

Kemampuan mengenal emosi diri sendiri

dan orang lain (I can)

Kemampuan menjalin relasi yang

terpercaya dengan orang lain (I can)

Relasi yang didasari oleh kepercayaan ( $I$ Regulasi emosi

have)

Bentuk relasi dalam keluarga dan Pengendalian impuls

lingkungan sosial (I have)

Model peran yang dijalani dalam kehidupan Optimisme

sosial (I have)

Dorongan individu untuk menjadi mandiri Pemahaman sebab akibat

(otonom) (I have)

Akses terhadap fasilitas kesehatan (I have) $\quad$ Empati

Penilaian personal positif terhadap diri Efikasi diri

sendiri $(\mathrm{I} \mathrm{am})$

R3

\begin{tabular}{ll}
\hline Memiliki empati terhadap orang lain (I am) & $\begin{array}{l}\text { Kemampuan melihat sisi } \\
\text { positif dari kemalangan }\end{array}$ \\
\hline $\begin{array}{l}\text { Memiliki tanggung jawab terhadap diri } \\
\text { sendiri (I am) }\end{array}$ & \\
\hline Optimis dan percaya diri (I am) \\
\hline Kemampuan komunikasi (I can) \\
\hline Kemampuan penyelesaian masalah (I can) \\
\hline Kemampuan mengelola emosi (I can) \\
\hline $\begin{array}{l}\text { Kemampuan memahami emosi diri sendiri } \\
\text { dan orang lain (I can) }\end{array}$ \\
$\begin{array}{l}\text { Kemampuan menjalin relasi yang } \\
\text { terpercaya dengan orang lain (I can })\end{array}$
\end{tabular}


R4 Relasi yang didasari oleh kepercayaan (I Regulasi emosi

\begin{tabular}{|c|c|}
\hline $\begin{array}{lccc}\text { Bentuk relasi dalam } & \text { keluarga } & \text { dan } \\
\text { lingkungan sosial (I have) } & & \\
\end{array}$ & Pengendalian impuls \\
\hline $\begin{array}{l}\text { Model peran yang dijalani dalam kehidupan } \\
\text { sosial (I have) }\end{array}$ & Optimisme \\
\hline $\begin{array}{l}\text { Dorongan individu untuk menjadi mandiri } \\
\text { (otonom) (I have) }\end{array}$ & Pemahaman sebab akibat \\
\hline Akses terhadap fasilitas kesehatan (I have) & Empati \\
\hline Penilaian positif terhadap diri sendiri ( $\mathrm{I} \mathrm{am})$ & Efikasi diri \\
\hline Memiliki empati terhadap orang lain ( $\mathrm{I} \mathrm{am}$ ) & $\begin{array}{l}\text { Kemampuan melihat sisi } \\
\text { positif dari kemalangan }\end{array}$ \\
\hline $\begin{array}{l}\text { Bertanggung jawab terhadap diri sendiri }(I \\
a m)\end{array}$ & \\
\hline Optimis dan percaya diri $(\mathrm{I} \mathrm{am})$ & \\
\hline Kemampuan komunikasi (I can) & \\
\hline Kemampuan penyelesaian masalah (I can) & \\
\hline Kemampuan mengelola emosi (I can) & \\
\hline $\begin{array}{l}\text { Kemampuan memahami emosi diri sendiri } \\
\text { dan orang lain (I can) }\end{array}$ & \\
\hline $\begin{array}{lcc}\text { Kemampuan menjalin relasi } & \text { yang } \\
\text { terpercaya dengan orang lain }(I \text { can }) & \end{array}$ & \\
\hline
\end{tabular}

\section{Diskusi}

Keempat partisipan dalam penelitian ini berhasil mengembangkan kemampuan resiliensi dan melewati fase krisis sebagai dampak infeksi COVID-19. Dalam situasi penuh ketidakpastian, kemampuan resiliensi dapat menjadi pembeda yang membantu individu tetap seimbang secara fisik dan psikologis (Vinkers, Amelsvoort, Bisson, Branchi, Cryan,...,Wee, 2020). Stres dan kecemasan merupakan respons alamiah individu dalam kondisi abnormal seperti pandemi. Penyintas termasuk kelompok masyarakat yang berisiko mengalami distres karena beberapa hal, antara lain adalah stigma sosial dan dampak jangka panjang akibat infeksi COVID-19. Bagi penyintas COVID-19, dinyatakan negatif dari virus merupakan kondisi yang sangat berbeda dengan pulih. Beberapa gejala umum jangka panjang yang dialami oleh penyintas adalah kelelahan kronis, nyeri otot, gangguan irama jantung, sakit kepala, masalah tidur, dan masalah kecemasan (Lambert \& Corps, 2020). Penyintas yang mengalami gejala jangka panjang COVID-19 mengalami hambatan yang signifikan dalam kehidupan sehari-hari, seperti menyelesaikan pekerjaan misalnya (Davis dkk., 2020). Kondisi ini pun dialami oleh partisipan R2 yang hingga tiga bulan pascanegatif COVID-19 masih mengalami anosmia dan kelelahan kronis. Kondisi tersebut membuat partisipan R2 belum mampu menjalankan perannya sebagai ibu rumah tangga secara optimal.

COVID-19 termasuk dalam keluarga coronavirus yang dapat memicu gangguan fisik bergejala ringan hingga berat. Ada dua tipe coronavirus yang dapat menimbulkan 
gangguan dan gejala berat yang sempat menjadi pandemi di tahun 2002 dan 2012, yaitu Severe Acute Respiratory Syndrome (SARS) dan Middle East Respiratory Syndrome (MERS). COVID-19 merupakan varian baru dari keluarga virus corona yang belum pernah teridentifikasi pada manusia. Virus penyebab COVID-19 dinamakan SARS-CoV-2 yang bersifat zoonosis (ditularkan lewat perantara hewan kepada manusia). Hingga saat ini, otoritas kesehatan dunia belum dapat memastikan jenis hewan yang menjadi sumber penularan awal COVID-19 ke manusia (Direktorat Jenderal P2P, 2020).

Beberapa gejala umum yang menandakan infeksi COVID-19 adalah gangguan pernapasan akut, demam, batuk, sesak napas, ditambah dengan gejala khas berupa kehilangan kemampuan penciuman (anosmia) (Kemenkes, 2020). Virus ini dapat menular dengan cepat lewat pertukaran udara di ruang tertutup atau lewat sentuhan dengan individu yang sebelumnya telah terinfeksi COVID 19. Saat terinfeksi, individu tidak langsung mengalami gejala karena COVID-19 memiliki masa inkubasi rerata 5-6 hari dan dengan masa inkubasi terpanjang hingga 14 hari. Kasus COVID-19 dengan gejala berat dapat menyebabkan gangguan pernapasan akut, pneumonia, hingga kematian (Kemenkes, 2020).

Kombinasi antara masalah fisik dan psikologis membuat penyintas rentan mengalami beberapa problem emosi seperti kecemasan, trauma, dan depresi (Singh dkk., 2020). Dalam banyak kasus, pasien yang telah pulih dari infeksi COVID-19 pun mengalami penolakan oleh komunitasnya. Stigma yang terkait dengan pandemi dan infeksi menular sangat memicu stres. Stigma sosial merupakan ancaman serius terhadap pasien, tenaga kesehatan, dan penyintas (Bagcchi, 2020). Stigam sosial seperti ini dialami oleh partisipan R2, R3, dan R4. Partisipan R2 dan R3 mendapatkan perlakuan berbeda dari lingkungan tempat tinggalnya, sementara partisipan R4 sempat dijauhi oleh rekan kerjanya yang notabene adalah tenaga kesehatan.

Pada penyintas, pengalaman selama melakukan karantina atau isolasi dapat menginisiasi respons emosional yang beragam, seperti kecemasan, gangguan tidur, serangan panik, hingga gejala trauma (Singh dkk., 2020). Efek psikologis akibat pemulihan pascainfeksi ditambah dengan stigma berdampak signifikan terhadap keberfungsian penyintas dalam kehidupan sehari-hari (Taylor, 2019). Oleh karena itu, penyintas COVID19 menghadapi tantangan besar agar mampu bangkit dan pulih secara fisik maupun psikologis.

Temuan utama dalam penelitian ini adalah pola pikir resilien dan dukungan keluarga sebagai faktor protektif resiliensi. Pola pikir resilien adalah persepsi seseorang terhadap 
peristiwa traumatis/tidak menyenangkan yang berdampak terhadap kemampuan penyelesaian masalah dan perilaku adaptif (Goldstein \& Brooks, 2015). Pola pikir ini muncul pada seluruh partisipan saat berada dalam fase isolasi dan menjalani perawatan karena COVID-19. Temuan tersebut dikuatkan oleh Hayter \& Dorstyn (2014) yang menyatakan bahwa resiliensi merupakan hasi dari proses penyesuaian diri terhadap kondisi kehidupan yang tidak menguntungkan. Proses tersebut dapat berbentuk adaptasi pola pikir yang memilih paradigma positif untuk melihat dan menyelesaikan masalah yang sedang dihadapi oleh individu tersebut (Reivich \& Shatté, 2002). Alih-alih terjebak dalam kemalangan dan kesedihan, keempat partisipan mampu memilih adaptasi yang tepat untuk menghadapi problem fisik dan psikis.

Beberapa riset terdahulu membuktikan bahwa penerimaan dan dukungan keluarga merupakan faktor kunci penentu resiliensi. Riset Kurniawan (2011) pada pasien talassemia menemukan bahwa kunci resiliensi terletak pada dukungan orangtua. Kondisi ini ditemukan pada partisipan R1 yang mendapatkan dukungan penuh dari orangtua selama menjalani perawatan di rumah sakit, wisma atlet, maupun kala melakukan isolasi mandiri. Partisipan R1 menjelaskan bahwa dukungan dari lingkungan terdekat seperti orangtua dan rekan kerja menjadi faktor utama yang membangkitkan semangat untuk pulih. Jika orangtua atau keluarga dapat menerima dan memberikan dukungan psikologis yang tepat, maka partisipan akan mampu membantu dirinya sendiri dengan strategi adaptasi yang tepat. Lester dkk (2014) menguatkan argumentasi tersebut dengan menyatakan bahwa peningkatan fungsi keluarga, terutama peran orangtua, akan membantu mengurangi stres pada anak yang mengalami masalah psikologis dan mempromosikan perikau resiliensi kepada seluruh anggota keluarga.

Penelitian lain tentang resiliensi pada orangtua pasien talassemia membuktikan bahwa resiliensi dapat muncul melalui serangkaian proses dukungan sosial yang diberikan oleh individu dengan kesamaan masalah (Kurniawan, Nashori, \& Sulistyarini, 2019). Hasil serupa pun ditemukan dalam riset mengenai resiliensi pada perempuan penyintas kekerasan dalam rumah tangga (KDRT), bahwa dukungan sosial dapat menginisiasi kemampuan bangkit pada individu yang memiliki problem fisik dan psikologi (Kurniawan \& Noviza, 2018). Dukungan sosial seperti ini diwujudkan oleh partisipan R1 dalam bentuk komunitas penyintas COVID-19 Indonesia yang diberi nama COVID Survivor Indonesia (CSI). Partisipan R2 pun turut menyumbangkan keilmuannya di bidang administrasi publik dalam bentuk edukasi kepada sesama penyintas. 
Resiliensi muncul sebagai dinamika proses interaksi antara faktor protektif dan faktor risiko. Faktor risiko utama yang dihadapi oleh keempat partisipan adalah stigma sosial dan gejala jangka panjang COVID-19 (disebut dengan long COVID/istilah lain sesuai dengan perkembangan riset terbaru). Seluruh partisipan sempat mengalami label negatif terkait kondisi mereka sebagai pasien dan penyintas COVID-19. Label tersebut memberikan dampak emosional dan ketidaknyamanan terhadap partisipan. Kemudian gejala jangka panjang COVID-19 pun berdampak terhadap pemulihan fisik dan psikologis penyintas. Partisipan R1 bahkan mengalami stres akibat dianggap terlalu banyak pikiran dan tidak mengalami gangguan apa pun oleh beberapa dokter. Di masa awal pandemi di Indonesia (Maret-Mei 2020), riset terkait dampak jangka panjang COVID-19 masih minim. Dengan demikian, informasi mengenai dampak lanjutan yang dapat dialami oleh penyintas pun masih dipenuhi ketidakpastian. Taylor (2019), dalam buku Psychology of Pandemics, menyatakan bahwa ketidakpastian merupakan salah satu unsur dalam pandemi yang dapat memicu stres dan kecemasan. Itulah mengapa stigma sosial dan dampak jangka panjang COVID-19 dikategorikan sebagai faktor risiko yang dapat mengurangi peluang individu untuk resilien.

Berdasarkan temuan penelitian, keempat partisipan berhasil mengembangkan seluruh komponen resiliensi, yaitu I have, I am, dan I can. Bila dijabarkan secara lebih detail, indikator utama yang dominan dari komponen I have adalah relasi sosial yang dilandasi oleh kepercayaan (trust) dalam bentuk dukungan dari orangtua dan pasangan. Indikator lainnya dari komponen I have yang dimiliki oleh keempat partisipan adalah akses terhadap fasilitas publik seperti akses kesehatan dan pendidikan. Saat mengalami gejala COVID-19, seluruh partisipan memiliki kemampuan akses terhadap layanan kesehatan. Pada komponen kedua, I am, keempat partisipan memiliki persepsi personal bahwa mereka diterima dan dicintai oleh keluarga. Indikator yang lain adalah optimisme dan memiliki kepedulian terhadap orang lain. Hal ini tampak dari sikap seluruh partisipan yang berkomitmen untuk menjadi edukator COVID-19 bagi pasien dan penyintas lainnya. Pada komponen I can, seluruh partisipan mampu mengembangkan kemampuan komunikasi interpersonal, kemampuan penyelesaian masalah, dan kemampuan mengelola emosi negatif. Pengembangan berbagai komponen resiliensi seperti kemampuan menghadapi hambatan dan tantangan serta mengembangkan dukungan sosial terlihat pada seluruh partisipan. Lewat pola pikir adaptif, partisipan mampu mengetahui kelebihan dan kekurangan, dan mampu menerima kondisi dirinya secara utuh. 
Dinamika resiliensi dipengaruhi oleh tujuh faktor (Reivich \& Shatté, 2002), yaitu regulasi emosi, kemampuan pengendalian impuls, optimisme, analisis kausal, empati, efikasi diri, dan kemampuan meraih aspek positif dari kemalangan (reaching out). Salah satu faktor dominan yang muncul pada seluruh partisipan adalah kemampuan meraih aspek positif dari kemalangan. Faktor ini merupakan penentu yang membuat partisipan R1 rela meluangkan waktunya untuk menginisiasi komunitas penyintas COVID. Faktor empati dan sikap mengasihi diri sendiri membuat partisipan mampu resilien dengan cara menerima kondisi diri terlebih dahulu. Pada fase awal terinfeksi COVID-19, muncul pemikiran apakah peristiwa itu benar-benar terjadi atau tidak. Ada penyangkalan dan pertanyaan pada diri partisipan, mengapa aku yang terinfeksi COVID-19. Kemudian proses isolasi dan perawatan mengajarkan partisipan untuk menyayangi diri sendiri dan memberikan ruang ekspresi emosi pada diri sendiri. Sikap mengasihi diri sendiri sangat terkait dengan munculnya resiliensi (Hayter \& Dorstyn, 2014).

Penerimaan diri positif menjadi faktor yang berperan terhadap peningkatan aspek spiritual. Keempat partisipan mampu mengubah perspektif negatif mengenai COVID-19 dan mampu menerima kondisi seperti apa adanya. Bogar \& Hulse-Killacky (2016) memisahkan penerimaan diri positif dalam satu faktor yang berbeda dari spiritual. Dalam kasus penyintas COVID-19 ini, spiritual terkait dengan kemampuan partisipan untuk mengenal hikmah dari setiap peristiwa yang dialami dalam menjalani kehidupan.

Aspek dukungan keluarga menjadi penting dan memiliki implikasi besar di masa depan karena keluarga adalah tempat individu belajar tentang relasi dengan orang lain. Penerimaan dan kepercayaan dari orangtua bisa membuat partisipan juga menerima keadaan dirinya. Peristiwa masa kecil ini berbekas dalam pola perilaku pasien talassemia di masa remaja dan dewasa. Jadi, interaksi antara partisipan dan keluarga bersifat resiprokal. Walsh (2020) mengungkapkan bahwa kemunculan resiliensi dipengaruhi oleh faktor individual, biologis, dan sumber daya lingkungan yang mendukung, salah satunya adalah dukungan keluarga dan dukungan sosial. Ketiga faktor tersebut harus saling berinteraksi untuk menghasilkan pola pikir dan perilaku resiliensi.

Peneliti menemukan bahwa keempat partisipan mengembangkan unsur keyakinan terhadap Tuhan dalam proses pemulihan fisik dan psikis. Unsur ini belum dibahas secara detail dalam kerangka teori awal yang digunakan oleh peneliti. Fenomena ini dapat dijelaskan dengan kerangka teori resiliensi Connor dan Davidson (2003; Ablah \& Dong, 2014) mengenai unsur spiritualitas dalam resiliensi. Individu yang memiliki masalah fisik atau psikis menggunakan unsur keyakinan dan spiritualitas untuk menguatkan diri 
mereka Unsur spiritual menjadi cara bagi individu yang mengalami hambatan psikologis untuk menyelesaikan masalah mereka (Hefti \& Büssing, 2018). Proses isolasi, dukungan sosial, dan pola pikir adaptif membantu partisipan untuk memiliki keyakinan bahwa mereka mampu melewati masalah yang disebabkan oleh COVID-19. Unsur spiritual dapat menciptakan makna terhadap seluruh peristiwa yang telah terjadi. Kolaborasi antara komponen pola pikir adaptif, kemampuan mengelola emosi, dukungan sosial dan faktor empati serta spiritual merupakan kunci keempat partisipan untuk bangkit dari masalah fisik dan psikologis yang disebabkan oleh COVID-19.

\section{Simpulan}

Berdasarkan hasil penelitian dan diskusi, peneliti menemukan bahwa dinamika resiliensi pada penyintas COVID-19 dalam penelitian ini muncul sebagai interaksi antara faktor protektif dan faktor risiko. Faktor protektif terdiri atas komponen I can, I have, dan I am ditambah dengan faktor empati dan spiritual. Faktor risiko yang dialami oleh partisipan dalam penelitian ini adalah stigma sosial dan dampak jangka panjang COVID19. Kolaborasi antara komponen pola pikir adaptif, kemampuan mengelola emosi, dukungan sosial dan faktor empati serta spiritual merupakan kunci keempat partisipan untuk bangkit dari masalah fisik dan psikologis yang disebabkan oleh COVID-19.

\section{Saran}

Penyintas dan pasien COVID-19 sangat membutuhkan dukungan dari keluarga dan kerabat terdekat. Oleh karena itu, keluarga dan kerabat penyintas diharapkan dapat menerima kondisi penyintas untuk meningkatkan pemulihan fisik dan psikologis. Peneliti juga menyarankan agar dilakukan riset kolaboratif interdisipliner (misalnya bidang kedokteran, psikologi, dan antropologi) untuk memahami dampak COVID-19 terhadap aspek fisiologis, emosi, perilaku, dan sosial budaya masyarakat. Penelitian terhadap penyintas perlu dikembangkan untuk memahami dampak psikologis pada kasus gejala jangka panjang COVID-19.

\section{Kepustakaan}

Ablah, E., \& Dong, F. (2014). [Erratum] A Modified CD-RISC: Including Previously Unaccounted for Resilience Variables.

Bagcchi, S. (2020). Stigma during the COVID-19 pandemic. The Lancet. Infectious Diseases, 20(7), 782.

Bogar, C. B., \& Hulse-Killacky, D. (2016). Resiliency determinants and resiliency processes among female adult survivors of childhood sexual abuse. Journal of Counseling \& Development, 84(3), 318-327. 
Davis, H. E., Assaf, G. S., McCorkell, L., Wei, H., Low, R. J., Re'em, Y., Redfield, S., Austin, J. P., \& Akrami, A. (2020). Characterizing Long COVID in an International Cohort: 7 Months of Symptoms and Their Impact. medRxiv.

Denzin, N. K., \& Lincoln, Y. S. (2013). The Sage handbook of qualitative research. sage.

Deterding, N. M., \& Waters, M. C. (2018). Flexible coding of in-depth interviews: A twentyfirst-century approach. Sociological methods \& research, 0049124118799377.

Direktorat Jenderal P2P, P. dan P. P. (2020). Pedoman Pencegahan dan pengendalian Coronavirus Disease (COVID-19). Direktorat Jenderal Pencegahan dan Pengendalian Penyakit Kementerian Kesehatan. https://covid19.kemkes.go.id/download/REV03_Pedoman_P2_COVID-19_Maret2020.pdf

Goldstein, S., \& Brooks, R. B. (2015). Why study resilience? Dalam Handbook of resilience in children (hlm. 3-14). Springer.

Hakim, M. A. (2020). Profiling Risiko Psikologis COVID-19 di Indonesia. Prodi Psikologi Fakultas Kedokteran Universitas Sebelas Maret.

Hayter, M., \& Dorstyn, D. (2014). Resilience, self-esteem and self-compassion in adults with spina bifida. Spinal cord, 52(2), 167.

Hefti, R., \& Büssing, A. (2018). Integrating religion and spirituality into clinical practice. MDPI-Multidisciplinary Digital Publishing Institute.

Hendriani, W. (2018). Resiliensi psikologis: Sebuah pengantar. Kencana.

Kahija, Y. L. (2017). Penelitian fenomenologis jalan memahami pengalaman hidup. Penerbit Kanisius.

Kementerian Kesehatan. (2020). Keputusan Menteri Kesehatan Nomor HK.01.07/Menkes/413/2020 tentang Pedoman Pencegahan dan Pengendalian Coronavirus Disease 2019 (COVID-19).

Kementerian Kesehatan. (2020). Info Corona Virus Archives» Info Infeksi Emerging Kementerian Kesehatan RI. Info Infeksi Emerging Kementerian Kesehatan RI. https://covid19.kemkes.go.id/category/situasi-infeksi-emerging/info-coronavirus/

Kementerian Kesehatan. (2020). Keputusan Menteri Kesehatan Republik Indonesia Nomor HK.01.07/Menkes/413/2020 tentang Pedoman Pencegahan dan Pengendalian Coronavirus Disease (COVID-19). Kementerian Kesehatan.

Kurniawan, Y. (2011). Pembentukan Resiliensi (Resilient Formation) Pada Penderita Thalassemia. Khazanah: Jurnal Mahasiswa, 4(1), 9-24.

Kurniawan, Y., Nashori, F., \& Sulistyarini, I. (2019). Terapi Kelompok Pendukung untuk Meningkatkan Resiliensi pada Ibu yang Memiliki Anak Talasemia. Psympathic: Jurnal Ilmiah Psikologi, 6(1), 31-40. 
Kurniawan, Y., \& Noviza, N. (2018). Peningkatan Resiliensi pada Penyintas Kekerasan terhadap Perempuan Berbasis Terapi Kelompok Pendukung. Psikohumaniora Jurnal Psikologi Universitas Islam Negeri Walisongo, 2(2), 125-142. http://dx.doi.org/10.21580/pjpp.v2i2.1968

Lambert, N. J., \& Corps, S. (2020). COVID-19 “long hauler" symptoms survey report.

Lester, P., Stein, J. A., Saltzman, W., Woodward, K., MacDermid, S. W., Milburn, N., Mogil, C., \& Beardslee, W. (2014). Psychological health of military children: Longitudinal evaluation of a family-centered prevention program to enhance family resilience. Military Medicine, 178(8), 838-845.

Liang, T. B. (2020). Buku Pegangan Pencegahan dan Penatalaksanaan COVID-19. Zhejiang University School of Medicine.

Mahase, E. (2020). Covid-19: What do we know about "long covid"? bmj, 370.

Pelupessy, D., \& Bramanwidyantri, M. (2020). Sebagian Besar Penyintas Covid-19 dan Keluarganya Mendapat Stigma (Riset Kerjasama Laporcovid-19 dan Kelompok Peminatan Intervensi Sosial Fakultas Psikologi Universitas Indonesia). https://laporcovid19.org/2020/08/sebagian-besar-penyintas-covid-19-dankeluarganya-mendapat-stigma/

Prime, H., Wade, M., \& Browne, D. T. (2020). Risk and resilience in family well-being during the COVID-19 pandemic. American Psychologist; American Psychological Association, 75(5), 631-643.

Ravando, R. (2020). Perang Melawan Influenza: Pandemi Flu Spanyol di Indonesia Masa Kolonial (1 ed.). Penerbit Buku KOMPAS.

Reivich, K., \& Shatté, A. (2002). The resilience factor: 7 essential skills for overcoming life's inevitable obstacles. Broadway Books.

Rizkiayu, A. (2020). Salah Kaprah Stigmatisasi dan Diskriminasi terhadap Pasien Covid-19 Halaman all-Kompas.com. https://www.kompas.com/tren/read/2020/04/13/164454765/salah-kaprahstigmatisasi-dan-diskriminasi-terhadap-pasien-covid-19?page=all

Satgas COVID-19, W. R. P. (2021). Data Pasien COVID-19 di Indonesia. covid19.go.id. https://covid19.go.id/

Setiawan, E. (2012). Kamus Besar Bahasa Indonesia (KBBI). Badan Pengembangan dan Pembinaan Bahasa, Kemdikbud (Pusat Bahasa), 2016.

Shereen, M. A., Khan, S., Kazmi, A., Bashir, N., \& Siddique, R. (2020). COVID-19 infection: Origin, transmission, and characteristics of human coronaviruses. Journal of advanced research, 24, 91-98.

Singh, S., Bhutani, S., \& Fatima, H. (2020). Surviving the stigma: Lessons learnt for the prevention of COVID-19 stigma and its mental health impact. Mental Health and Social Inclusion, 24(3), 145-149. https://doi.org/10.1108/MHSI-05-2020-0030 
Susanto, A. D. (2021). Clinical picture and quality of life of post-COVID-19 patient in Indonesia. The 18th Scientific Respiratory Medicine Meetiing.

Taylor, S. (2019). The psychology of pandemics: Preparing for the next global outbreak of infectious disease. Cambridge Scholars Publishing.

UNICEF, \& WHO. (2020). Stigma Sosial terkait dengan COVID-19: Panduan untuk Mencegah dan Mengatasi Stigma Sosial.

Vinkers, C. H., van Amelsvoort, T., Bisson, J. I., Branchi, I., Cryan, J. F., Domschke, K., Howes, O. D., Manchia, M., Pinto, L., \& de Quervain, D. (2020). Stress resilience during the coronavirus pandemic. European Neuropsychopharmacology, 35, 12-16.

Walsh, F. (2020). Loss and resilience in the time of COVID-19: Meaning making, hope, and transcendence. Family process, 59(3), 898-911.

WHO, W. H. O. (2020). What we know about Long-term effects of COVID-19 (hlm. 1-20). World Health Organization. 